Jpn J Human Genet 41, 407-411, 1996

Short Communication

\title{
NOVEL MISSENSE AND FRAMESHIFT MUTATIONS IN THE ADRENOLEUKODYSTROPHY GENE
}

\author{
Hisao Ueyama, ${ }^{1, *}$ Tsunekazu Yamano, ${ }^{2}$ Morimi Shimada, ${ }^{2}$ \\ and Iwao OHKUBO ${ }^{1}$ \\ Departments of ${ }^{1}$ Medical Biochemistry and ${ }^{2}$ Pediatrics, Shiga University of \\ Medical Science, Seta, Otsu 520-21, Japan
}

Key Words adrenoleukodystrophy, ALD gene, missense mutation, frameshift mutation, de novo mutation

$\mathrm{X}$-linked adrenoleukodystrophy (ALD) is an inborn error of metabolism characterized by the accumulation of very-long-chain fatty acids in the white matter of the nervous system and in the adrenal cortex, resulting in progressive demyelination and adrenal insufficiency. In 1993 a candidate gene for ALD was isolated (Mosser et al., 1993). The protein encoded by this gene consists of 745 amino acids and is similar to a peroxisomal membrane protein, PMP70, in terms of the domain structure and the amino acid sequence. Analyses of the reversetranscribed ALD mRNA and the ALD gene (Mosser et al., 1993; Cartier et al., 1993; Uchiyama et al., 1994; Kemp et al., 1994, 1995; Matsumoto et al., 1994; Berger et al., 1994; Fanen et al., 1994; Barceló et al., 1994, 1995; Fuchs et al., 1994; Ligtenberg et al., 1995; Braun et al., 1995; Yasutake et al., 1995; Song et al., 1995; Vorgerd et al., 1995; Kok et al., 1995; Koike et al., 1995; Krasemann et al., 1996) revealed that the defects in ALD patients are heterogeneous, which may be summarized as follows: large deletions $(\sim 7 \%)$, missense $(\sim 53 \%)$, frameshift $(\sim 29 \%)$, and nonsense $(\sim 5 \%)$ mutations, splice defects $(\sim 5 \%)$, and amino acid insertions and deletions $(\sim 1 \%)$. In this study, we investigated two Japanese ALD patients from two families by the PCR of genomic DNA and subsequent sequencing, and found novel mutations in the ALD gene.

PCR primers used for the amplification of exon 2 were $5^{\prime}$ CACTGGGAGACCCTGAC3' and 5'GGCGGGCTGGCTGAGTT3'. Exons 3 and 4, and exons 6 and 7 were amplified together, and exons $8-10$ by nested-PCR. PCR primers for exons 6 and 7 were 5'ATTGGGAGCCTCTCAAG3' and 5'GCACCTGGCACTTTAGA3'. Some investigators found difficulties in the PCR of exons 8-10 (Fanen

Received June 14, 1996; Revised version accepted August 7, 1996.

* To whom correspondence should be addressed. 
et al., 1994) and exons 7-10 (Fuchs et al., 1994), due to the presence of a related pseudogene (Braun et al., 1996), but we could successfully amplify these exons. Genomic DNA was extracted from peripheral blood leukocytes and $100 \mathrm{ng}$ was used as a template in the PCR. Direct sequencing of the amplified fragments was performed with either of the PCR primers. Only for exon 1 the products were cloned into a plasmid, pUC119, and sequenced. Two internal PstI sites, which gave $283 \mathrm{bp}, 189 \mathrm{bp}$ and $579 \mathrm{bp}$ fragments upon cleavage of the product (1,051 bp) with the enzyme, were used for subcloning and sequencing. When a point mutation was found, other subclones from the same patient were examined for verification. With regard to exons 9 and 10 , two internal primers were also used for direct sequencing.
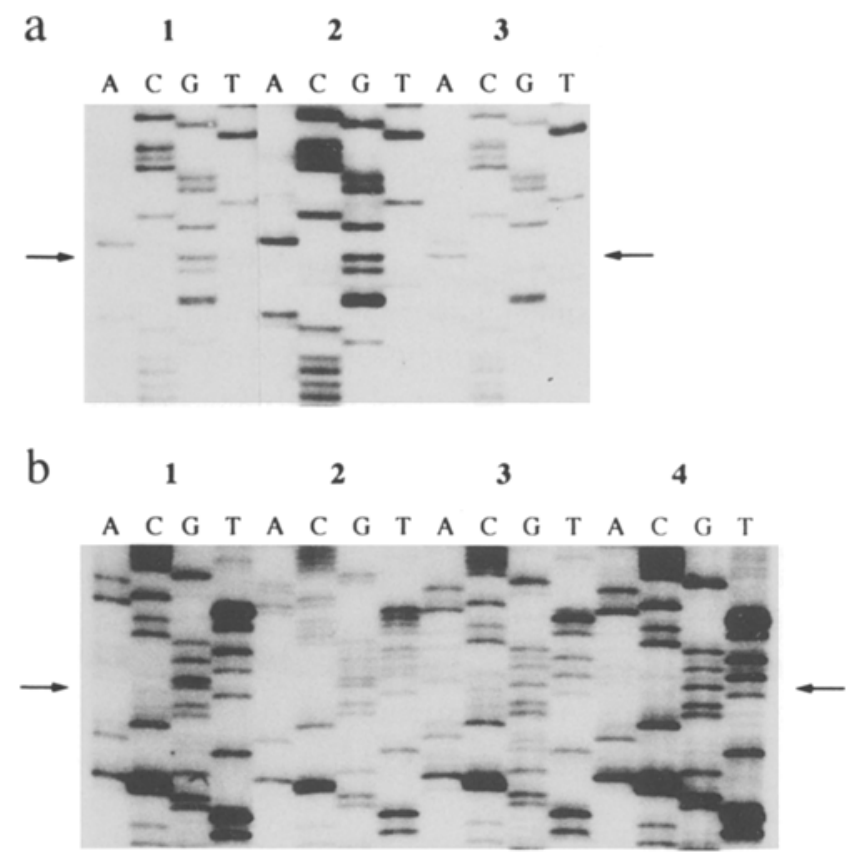

Fig. 1. Mutations found in two Japanese ALD patients. (a) Exon 2 was PCRamplified from the genomic DNA and directly sequenced with the upstream primer. The autoradiogram reads CCCCGCAGGTGGAGCTGGCCCTGC in the control (lane 1), but the $\mathrm{G}$ (nucleotide number = 1290) is " $\mathrm{A}$ " (indicated by an arrow) in the patient (lane 3 ). This is a missense mutation at codon 302 (Glu $\rightarrow$ Lys), which occurred de novo, because the mother is normal at this site (lane 2). (b) Exon 6 was PCR-amplified from the genomic DNA and directly sequenced with the upstream primer. It reads CTCTGGCCCACGTACGGTGGTGTGCTCTACAAGCCCC in the control (lane 1), but the G (nucleotide number $=1971$ ) is deleted (indicated by an arrow) in the patient (lane 3) and also in his younger brother (lane 4). Since the mother is heterozygous for the mutation, the sequence beyond this site is hardly readable (lane 2 ). 
One of the patients (H.Y.) showed a gait disturbance at the onset of the disease at age 10 years, and spastic quadriplegia, blindness, deafness and adrenal failure became evident later. He was finally diagnosed as ALD from the level of very-long-chain fatty acids in erythrocyte membrane sphingomyelin (Tanaka et al., 1986) and by histologic examination of the rectal mucosa for cytoplasmic lamellar inclusions (Tanaka et al, 1987). On analysis of the ALD gene of the patient, we found a missense mutation in exon 2 (Glü302 $\rightarrow$ Lys, G1290A) (Fig. la), which was the only abnormality present in the 10 exons and their adjacent introns we sequenced. This is the first report on a mutation present in exon 2 . The Glu ${ }^{302}$ exists in the intraperoxisomal region between the fifth and the sixth membranespanning domains, and conserved in the mouse homologue of ALD protein (Sarde et al., 1994), and in the human and rat PMP70 proteins (corresponding to Glu ${ }^{288}$ ) (Kamijo et al., 1992). There have been four reports on a missense mutation in this intraperoxisomal region: G1182A (Gly ${ }^{266} \rightarrow$ Arg) (Ligtenberg et al., 1995; Fuchs et al., 1994), G1215T (Gly $\left.{ }^{277} \rightarrow \operatorname{Trp}\right)$ (Kok et al., 1995), G1215A (Gly ${ }^{277} \rightarrow \operatorname{Arg}$ ) (Krasemann et al., 1996), and G1257A (Glu ${ }^{291} \rightarrow$ Lys) (Cartier et al., 1993). These mutations and the one we found, all causing drastic substitutions of amino acids, may impair stability of the ALD protein. It is of interest that the patient's mother is normal for this site (Fig. 1a), indicating that the mutation arose de novo. Such a de novo mutation of the ALD gene was also reported by others (Fanen et al., 1994; Barceló et al., 1995; Krasemann et al., 1996). The mother showed as high a level of tetracosanoic (C24:0) and hexacosanoic (C26:0) acids in erythrocyte membrane sphingomyelin as hemizygous patients (Tanaka et al., 1986). The discrepancy between the DNA and lipid analyses can be explained by germinal (and/or somatic) mosaicism, or it may simply suggest that lipid analysis is sometimes misleading in the carrier detection of ALD.

The other patient (K.A.) noticed visual impairment at the age 5 years. He later developed spastic quadriplegia, blindness and deafness, but no signs of adrenal failure until his death. The examinations by computed tomography of the skull for demyelination (Tanaka et al., 1986), by rectal biopsy for lamellar inclusion bodies (Tanaka et al., 1987), and of very-long-chain fatty acid content in the erythrocyte membrane (Tanaka et al., 1986) led to his final diagnosis of ALD. On analysis of the ALD gene of the patient, we found a frameshift mutation in exon 6 (Gly ${ }^{529}$ frameshift, 1971delG) (Fig. 1b), which causes premature termination of translation at nucleotides 2048-2050 (TGA), resulting in the elimination of one of the two ATP-binding cassettes (corresponding to nucleotides 2235-2276). Twenty-seven ALD cases have been suggested to be caused by frameshift mutations (Kemp et al., 1994; Ligtenberg et al., 1995; Braun et al., 1995; Song et al., 1995; Fanen et al., 1994; Barceló et al., 1994; Fuchs et al., 1994; Kok et al., 1995; Krasemann et al., 1996), more than a half of them being the same defect (1801delAG), but the mutation we found has never been reported. The patient's mother is heterozygous for this site and his younger brother (S.A.) has the same deletion (Fig. 1b). Though 
the younger brother showed a high level of very-long-chain fatty acids in erythrocyte membrane sphingolipids and had lamellar inclusions in the biopsy specimen of rectal mucosa (Tanaka et al., 1987), he has not yet manifested any clinical symptoms since these examinations were held (about 10 years ago). This is an example of variability of ALD, suggesting additional environmental and/or genetic factors influencing the phenotype.

\section{REFERENCES}

Barceló A, Girós M, Sarde CO, Martỉnez-Bermejo A, Mandel JL, Pàmpols T, Estivill X (1994): Identification of a new frameshift mutation (1801delAG) in the ALD gene. Hum Mol Genet 3: $1889-1890$

Barceló A, Girós M, Sarde CO, Pintos G, Mandel JL, Pàmpols T, Estivill X (1995): De novo missense mutation Y174S in exon 1 of the adrenoleukodystrophy (ALD) gene. Hum Genet 95: $235-237$

Berger J, Molzer B, Faé I, Bernheimer H (1994): X-linked adrenoleukodystrophy (ALD): a novel mutation of the ALD gene in 6 members of a family presenting with 5 different phenotypes. Biochem Biophys Res Commun 205: 1638-1643

Braun A, Ambach H, Kammerer S, Rolinski B, Stöckler S, Rabl W, Gärtner J, Zierz S, Roscher AA (1995): Mutations in the gene for X-linked adrenoleukodystrophy in patients with different clinical phenotypes. Am J Hum Genet 56: 854-861

Braun A, Kammerer S, Ambach H, Roscher AA (1996): Characterization of a partial pseudogene homologous to the adrenoleukodystrophy gene and application to mutation detection. Hum Mutat 7: 105-108

Cartier N, Sarde C-O, Douar A-M, Mosser J, Mandel J-L, Aubourg P (1993): Abnormal messenger RNA expression and a missense mutation in patients with X-linked adrenoleukodystrophy. Hum Mol Genet 2: 1949-1951

Fanen P, Guidoux S, Sarde C-O, Mandel J-L, Goossens M, Aubourg P (1994): Identification of mutations in the putative ATP-binding domain of the adrenoleukodystrophy gene. $J$ Clin Invest 94: $516-520$

Fuchs S, Sarde CO, Wedemann H, Schwinger E, Mandel JL, Gal A (1994): Missense mutations are frequent in the gene for X-chromosomal adrenoleukodystrophy (ALD). Hum Mol Genet 3: $1903-1905$

Kamijo K, Kamijo T, Ueno I, Osumi T, Hashimoto T (1992): Nucleotide sequence of the human $70 \mathrm{kDa}$ peroxisomal membrane protein: a member of ATP-binding cassette transporters. Biochim Biophys Acta 1129: 323-327

Kemp S, Ligtenberg MJL, van Geel BM, Barth PG, Wolterman RA, Schoute F, Sarde C-O, Mandel J-L, van Oost BA, Bolhuis PA (1994): Identification of a two base pair deletion in five unrelated families with adrenoleukodystrophy: a possible hot spot for mutations. Biochem Biophys Res Commun 202: 647-653

Kemp S, Ligtenberg MJL, van Geel BM, Barth PG, Sarde C-O, van Oost BA, Bolhuis PA (1995): Two intronic mutations in the adrenoleukodystrophy gene. Hum Mutat 6: 272-273

Koike R, Onodera O, Tabe H, Kaneko K, Miyatake T, Iwasaki S, Nakano M, Shizuma N, Ikeguchi K, Nishizawa M, Mosser J, Sarde C-O, Tsuji S (1995): Partial deletions of putative adrenoleukodystrophy (ALD) gene in Japanese ALD patients. Hum Mutat 6: 263-267

Kok F, Neumann S, Sarde C-O, Zheng S, Wu K-H, Wei H-M, Bergin J, Watkins PA, Gould S, Sack G, Moser H, Mandel J-L, Smith KD (1995): Mutational analysis of patients with X-linked adrenoleukodystrophy. Hum Mutat 6: 104-115

Krasemann EW, Meier V, Korenke GC, Hunneman DH, Hanefeld F (1996): Identification of mutations in the ALD-gene of 20 families with adrenoleukodystrophy/adrenomyeloneuropathy. Hum Genet 97: 194-197 
Ligtenberg MJL, Kemp S, Sarde C-O, van Geel BM, Kleijer WJ, Barth PG, Mandel J-L, van Oost BA, Bolhuis PA (1995): Spectrum of mutations in the gene encoding the adrenoleukodystrophy protein. Am J Hum Genet 56: 44-50

Matsumoto T, Kondoh T, Masuzaki H, Harada N, Matsusaka T, Kinoshita E, Takeo G, Tsujihata M, Suzuki Y, Tsuji Y (1994): A point mutation at ATP-binding region of the ALD gene in a family with X-linked adrenoleukodystrophy. Jpn J Human Genet 39: 345-351

Mosser J, Douar A-M, Sarde C-O, Kioschis P, Feil R, Moser H, Poustka A-M, Mandel J-L, Aubourg P (1993): Putative X-linked adrenoleukodystrophy gene shares unexpected homology with $\mathrm{ABC}$ transporters. Nature 361: 726-730

Sarde C-O, Thomas J, Sadoulet H, Garnier J-M, Mandel J-L (1994): cDNA sequence of Aldgh, the mouse homolog of the X-linked adrenoleukodystrophy gene. Mamm Genome 5: 810-813

Song X-Q, Fukao T, Suzuki Y, Imamura A, Uchiyama A, Shimozawa N, Kondo N, Orii T (1995): Identification of a novel frameshift mutation in a Japanese adrenoleukodystrophy patient. Hum Mol Genet 4: 1093-1094

Tanaka K, Shimada M, Naruto T, Yamamoto H, Saeki Y, Sai H, Hirose G (1986): Very long-chain fatty acids in erythrocyte membrane sphingomyelin: detection of ALD hemizygotes and heterozygotes. Neurology 36: 791-795

Tanaka K, Yamano T, Shimada M, Ohno M, Onaga A, Saeki Y, Kodama S, Nishio H (1987): Electronmicroscopic study on biopsied rectal mucosa in adrenoleukodystrophy. Neurology 37: $1012-1015$

Uchiyama A, Suzuki Y, Song X-Q, Fukao T, Imamura A, Tomatsu S, Shimozawa N, Kondo N, Orii T (1994): Identification of a nonsense mutation in ALD protein cDNA from a patient with adrenoleukodystrophy. Biochem Biophys Res Commun 198: 632-636

Vorgerd M, Fuchs S, Tegenthoff M, Malin J-P (1995): A missense point mutation (Ser515Phe) in the adrenoleukodystrophy gene in a family with adrenomyeloneuropathy: a clinical, biochemical, and genetic study. J Neurol Neurosurg Psychiatry 58: 229-231

Yasutake T, Yamada T, Furuya H, Shinnoh N, Goto I, Kobayashi T (1995): Molecular analysis of X-linked adrenoleukodystrophy patients. J Neurol Sci 131: 58-64 